\title{
Comparison of methods for the determination of calcium in plant material
}

\author{
J. CH. VAN SCHOUWENBURG
}

Laboratory of Soils and Fertilizers, Agricultural State University, Wageningen, and Institute for Soil Fertility, Groningen, Netherlands

\begin{abstract}
Summary
Several different methods for the determination of calcium in plant material have been tested. It is shown that dry ashing leads to low results in comparison with wet ashing or extraction with normal hydrochloric acid.

Furthermore a new complexometric method for the determination of calcium is proposed in which no magnesium interference occurs. In combination with a normal hydrochloric acid extract of plant material no chemical separations are needed.
\end{abstract}

\section{Introduction}

The method most widely used for the determination of calcium in plant material will probably be the dry ashing of the sample followed by repeated moistening and evaporation with hydrochloric acid to render the silicium oxide insoluble (Anon., 1955). The determination is finished by oxalate precipitation and oxydimetric titration (M e thod 1).

SCHARRer and Munk (1956) and later Grosse-BrauckmanN (1958) raised objections against the dry ashing procedure because it may result in too low recoveries of calcium, caused by the formation of insoluble calciumsilicates.

To see whether the wet ashing procedure of LindNER and HARLEY $(1942,1944)$ leads to higher results in comparison with a dry ashing procedure this digestion method was used in connection with a complexometric estimation of the calcium (M e thod 2). Besides this digestion offers the possibility of determining Kjeldahl nitrogen, phosphorus, potassium, sodium and magnesium in the same digest (SCHuFFELEN et al., 1961).

The cation interferences with the complexometric determination of calcium are, in this method, suppressed by the use of potassiumcyanide and triethanolamine. The influence of magnesiumhydroxide is opposed by the use of sodiumcarboxymethylcellulose ("Nymcel Z.L.C." a low viscosity protective colloid obtainable from "Nijma", Nijmegen, The Netherlands; vaN SchouwEnburg, 1960). If an indicator insensitive to magnesium is used, for instance calcein (DIEHL and EllingBoe, 1956) mixed with thymolphthalein (TUCKER, 1957), no magnesium interference will occur.

The phosphate interference is anticipated by a liquid-liquid extraction based on the work of COLLIER (1954).

Received for publication 15th May, 1961. 
The influence of several interfering ions with the complexometric determination of $1 \mathrm{mg}$ of calcium has been chequed as follows :

\begin{tabular}{|c|c|}
\hline $\begin{array}{c}\text { mg of interfering } \\
\text { element }\end{array}$ & $\begin{array}{l}\text { Percentage recovery } \\
\text { of calcium }\end{array}$ \\
\hline $2 \mathrm{mg} \mathrm{Mg}$ & 100 \\
\hline $1 \mathrm{mg} \mathrm{Fe} 3+$ & 99 \\
\hline $1 \mathrm{mg} \mathrm{Fe} 2+$ & 99 \\
\hline $1 \mathrm{mg} \mathrm{Pb}$ & 100 \\
\hline $1 \mathrm{mg} \mathrm{Al}$ & 99 \\
\hline $1 \mathrm{mg} \mathrm{Co}$ & 101 \\
\hline $1 \mathrm{mg} \mathrm{Ni}$ & 100 \\
\hline $1 \mathrm{mg} \mathrm{Zn}$ & 100 \\
\hline $1 \mathrm{mg} \mathrm{Mn}$ & $99 *$ \\
\hline
\end{tabular}

* End point difficult to observe.

The easiest way of extracting calcium from plant material seems to be shaking with normal hydrochloric acid. When starting with an extract there is a possibility of less phosphate going into solution than is the case with a digestion. This being true the complexometric determination of calcium does not need a separation of phosphates (Method 3).

Since both a digest according to Lindner and Harley and a hydrochloric acid extract were already available it seemed a pity not to try whether a rapid flame-photometric determination of calcium could be adapted to the digestion ( $\mathrm{M} \mathrm{ethod} \mathrm{4)} \mathrm{or} \mathrm{the}$ extraction ( $\mathrm{M}$ e $\mathrm{t}$ h od 5 ).

When the flame-photometric method is used difficulties may arise from the high phosphate content of the material. It is however possible to decrease this interference within reasonable proportions by a "substitution process". At variance with PIETKA and CHUN (1959) who use barium or strontium for this purpose, an excess of magnesiumchloride is used. The boror and aluminium content of the samples is, in comparison with the calcium level, too low to cause appreciable deviations. The interference of sulphates will be concealed by the excess of sulphates originating from the digestion. In the case of the hydrochloric acid extract sulphates might cause low' recoveries.

The standard series for these flame-photometric determinations have to be made with the same hydrochloric- or sulphuric-acid contents as the samples.

Another method was investigated in which the dry ashing was replaced by wet ashing with nitric- and perchloric-acid (Anon., 1960). The digestion is finished by solution of the residue in hydrochloric acid followed by oxalate precipitation and oxydimetric titration (M e thod 6).

\section{Analytical methods}

Method 1: Dry ashing followed by oxydimetrictitration The determinations have been performed by the "Laboratory for Soil and Crop testing" at Oosterbeek, The Netherlands. The method used differs only in detail from the official methods of analysis of the A.O.A.C. (Anon. (1955) p. 101 : Calcium macro-method). 
Method 2: Sulphuric acid and peroxide digestion followed by separation of phosphate prior to complexometrictitration

\section{a. Digestion according to Lindner and Harley}

Weigh $0,6 \mathrm{~g}$ of plant material into a digestion vessel. Add $5 \mathrm{ml}$ of concentrated sulphuric acid and heat moderately on a hotplate during 15 minutes. The colour will turn to brownish-black. The sample should be swirled regularly to prevent foam formation. If foaming starts add not more than $1-2$ drops of hydrogen peroxide (30\%, A.R.). After 15 minutes 5-10 drops of hydrogen peroxide are added and this procedure is repeated every 10 minutes untill the solution is clear. The temperature of the hotplate is now raised to full heat $\left(300^{\circ} \mathrm{C}\right)$ and peroxide is added when the solution turns brown again. Repeat these additions untill the solution stays clear during 10 minutes. Cool the residue and transfer quantitatively into a $100 \mathrm{ml}$ volumetric flask. Make up to the mark with distilled water and filter. After the digestion only $3,5-4 \mathrm{ml}$ of the originally present $5 \mathrm{ml}$ of sulphuric acid will be left over. For this reason only $4 \mathrm{ml}$ of sulphuric acid are added in the blank determination.

\section{b. Separation of phosphate}

This separation has been carried out by a modified procedure based on the work of Collier (1954).

Re a gents: 1. ammoniummolybdate solution: dissolve $45 \mathrm{~g}$ of ammoniummolybdate and $40 \mathrm{ml}$ of concentrated sulphuric acid (s.g. 1,84) to 1 litre with distilled water ; 2 . extraction mixture : mix equal volumes of chloroform and $n$-butanol.

Separation: pipet into a $150 \mathrm{ml}$ separating funnel $15 \mathrm{ml}$ of the digest and add $10 \mathrm{ml}$ of molybdate solution. Mix and extract the phosphomolybdate complex with two portions of $20 \mathrm{ml}$ and one portion of $10 \mathrm{ml}$ of the extraction mixture. Shake one minute during each extraction. Run off the yellow coloured organic layer. Later work showed that a single extraction with $35 \mathrm{ml}$ of ethylacetate also removed sufficient phosphates to allow an undisturbed titration.

\section{c. The complexometric titration}

$\mathrm{R}$ e a ge n t s: $1.0,5 \%$ Nymcel Z.L.C. in distilled water; 2 . masking agent : dissolve $3,2 \mathrm{~g}$ of potassiumcyanide, $25 \mathrm{ml}$ of triethanolamine and $100 \mathrm{ml}$ of Nymcel Z.L.C. $0,5 \%$ to a total volume of $200 \mathrm{ml}$ with distilled water; 3. sodiumhydroxide $2 \mathrm{~N}$; 4. indicator mixture : grind to a fine powder $0,2 \mathrm{~g}$ of Calcein, $0,12 \mathrm{~g}$ ot thymolphthalein and $20 \mathrm{~g}$ of potassiumchloride; 5. EDTA $0,01 \mathrm{~N}$ standardized against calcium(carbonate). Because the potassiumcyanide and the Nymcel might contain interfering impurities, the EDTA solution has to be checked against increasing quantities of calcium standard every time new reagents are used. In this case the results can be evaluated graphically.

Treat me $\mathrm{nt}$ of $\mathrm{samples}:$ pipet $8 \mathrm{ml}$ of the digest into a $100 \mathrm{ml}$ beaker. Add successively : $30 \mathrm{ml}$ of distilled water, $6 \mathrm{ml}$ of sodiumhydroxide $2 \mathrm{~N}, 2 \mathrm{ml}$ of the masking agent, $3 \mathrm{ml}$ of sodiumhydroxide $2 \mathrm{~N}$ and a knifepoint of the indicator mixture. Titrate with EDTA 0,01 N.

If the content in the sample is too low, more digest may be taken. In this case proportionally more sodiumhydroxide is needed to neutralize the solution before adding the potassiumcyanide containing masking agent. 
Because of the fluorescence of the indicator the light source needs some consideration. Diffuse daylight entering sideways and a white paper background met our needs.

Method 3: Hydrochloric acid extraction followed by complexometric titration

\section{a. The extraction}

Shake with a mechanical shaker during two hours $0,6 \mathrm{~g}$ of plant material, $0,3 \mathrm{~g}$ of Norit XNK (an absorptive coal obtainable from the "N.V. Norit Vereeniging Verkoop Centrale", Amsterdam, The Netherlands) and $50 \mathrm{ml}$ of hydrochloric acid $1 \mathrm{~N}$. Filter. The Norit is intended to get a clear extract (van Schouwenburg, 1959).

\section{b. The complexometric titration}

Reagents: see Method 2 under $c$.

Treatment of $\mathrm{samples}$ : pipet $5 \mathrm{ml}$ of the extract into a $100 \mathrm{ml}$ beaker. Add successively $30 \mathrm{ml}$ of distilled water, $3 \mathrm{ml}$ of sodiumhydroxide $2 \mathrm{~N}, 2 \mathrm{ml}$ of the masking agent, $3 \mathrm{ml}$ of sodiumhydroxide $2 \mathrm{~N}$ and a knife point of the indicator mixture. Titrate with EDTA $0,01 \mathrm{~N}$.

Method 4: Sulphuric acid and peroxide digestion followed by flame photometry

a. Digestion: see Method 2 under a.

b. Flame-photometric determination

The determinations have been performed with a Kipp flame-photometer (Kipp ; Delft ; The Netherlands) using propane as fuel.

Because of the high acidity the digests have been diluted $1: 9(\mathrm{v} / \mathrm{v})$ with distilled water.

St a ndard solution: weigh $0,3003 \mathrm{~g}$ of calciumcarbonate into a 1 litre volumetric flask. Add hydrochloric acid $1 \mathrm{~N}$ untill all carbonate has dissolved. Add about $900 \mathrm{ml}$ of distilled water and $4 \mathrm{ml}$ of concentrated sulfuric acid and fill to the mark. The concentration of this standard solution corresponds with $500 \mathrm{mmol}$ of calcium per $100 \mathrm{~g}$ of air dry plant material and has the same concentration of sulphuric acid as the diluted samples.

Treat ment of samples and standard series: pipet into hard glass test tubes $1 \mathrm{ml}$ of the digest and add $9 \mathrm{ml}$ of distilled water. From a standard series $10 \mathrm{ml}$ is pipetted into hard glass test tubes. To samples and standards are added $2,5 \mathrm{ml}$ of magnesiumchloride $5,00 \mathrm{~N}$. Measure with the flame photometer.

Method 5: Hydrochloric acid extraction followed by flame photometry

a. The extraction: see Method 3 under a.

b. Flame-photometric determination

The determination is carried out in the $1: 9(\mathrm{v} / \mathrm{v})$ diluted extract because of the high acidity. The standard series is accordingly made up in hydrochloric acid $0,1 \mathrm{~N}$.

Standard solution: in a volumetric flask of 1 litre $0,6006 \mathrm{~g}$ of cal- 
ciumcarbonate is dissolved and made up to the mark with hydrochloric acid $0,1 \mathrm{~N}$. The concentration of this standard solution corresponds with $500 \mathrm{mmol}$ of calcium per $100 \mathrm{~g}$ of air dry plant material.

Treat ment of s a m les and standard series: pipet into hard glass test tubes $1 \mathrm{ml}$ of the extract and add $9 \mathrm{ml}$ of distilled water. Of a standard series $10 \mathrm{ml}$ are pipetted into hard glass test tubes. To standard and samples are added $2,5 \mathrm{ml}$ of magnesiumchloride 5,00 $\mathrm{N}$. Measure with the flame-photometer.

\section{Method 6: Nitric-perchloric acid digestion followed by oxydimetric titration}

The method of the "Experimental Station for Fruit and Vegetables under Glass" at Naaldwijk, The Netherlands, has been used (Private communication). First the sample is predigested two times with nitric acid. Next the digestion is finished with perchloric acid (70\%). The white residue is dissolved in hydrochloric acid, neutralized and calcium is precipitated as the oxalate. The precipitate is filtered off, washed and dissolved in hot sulphuric acid. The calcium content is estimated with a potassium permanganate titration.

\section{Results and discussion}

The calcium content of 19 plant samples has been determined according to the methods described above (see TABLE).

The standard deviation of $\mathrm{m}$ e $\mathrm{th}$ ods 1,2 and 3 is much smaller than for $\mathrm{met} h$ od $\mathrm{s}$ 4 and 5. M e th od 6 has not been included in the mathematical evaluation of the results because of insufficient repetitions of the determinations. Nevertheless the data correspond so well with those of $\mathrm{methods} 2$ and 3 that it was thought advisable to publish the results.

Comparing the results of $\mathrm{method} 1$ with those of $\mathrm{method} 2$ or 3 it is obvious that $\mathrm{method} 1$ produces lower data. When the sign test is applied to the differences between $\mathrm{method} 1$ and 2 or to the differences of $\mathrm{method} 1$ and 3 , these differences appear to be very significant $(P=0,01)$ even with a two sided test. The results of $\mathrm{method} 2$ and 3 however agree very well.

Analytically method 1 and 6 differ only in their digesting phase. In all but one case (sample 8) the results of $\mathrm{method} 6$ are equal or higher than those of $\mathrm{met} h$ od 1 . These results seem to confirm the findings of ScharRer and MuNK and of Grosse-BrauckMaNN that dry ashing may lead to low results.

Met hod 3 proves that an extraction with normal hydrochloric acid dissolves all of the available calcium. The agreement with $\mathrm{methods} 2$ and 6 is striking which seems to confirm the supposition that no significant phosphate influence is interfering with the results. In fact, this method proves to be a very easy, quick and reliable way of determining calcium in plant material.

The flame-photometric determination of calcium either in a Lindner-Harley digest or a hydrochloric acid extract (method 4 and 5 respectively) has for some time been checked in this laboratory for the routine determination of calcium in plant material. The method is very manageable and quick but the results do not satisfy. In the case of the digest the data are significantly $(P=0,01)$ lower than those of $\mathrm{met}$ h od 2 or 3. Nevertheless these differences nowhere become serious. Flame-photometry in 
TABLE. Comparison of different methods used for the determination of calcium in plant material (data expressed as mmol $\mathrm{Ca}$ per $100 \mathrm{~g}$ of oven dried $\left(105^{\circ} \mathrm{C}\right)$ material)

\begin{tabular}{|c|c|c|c|c|c|c|}
\hline \multirow[t]{2}{*}{ Crop } & \multicolumn{6}{|c|}{ Method } \\
\hline & 1 & 2 & 3 & 4 & 5 & 6 \\
\hline 1. beet, tuber $\ldots \ldots \ldots \ldots \ldots \ldots$ & 4 & 8 & 7 & 8 & 23 & 6 \\
\hline 2. asparagus, straw $\ldots \ldots \ldots$ & 10 & 11 & 11 & 11 & 12 & 11 \\
\hline 3. asparagus, straw $\ldots \ldots \ldots \ldots$ & 12 & 13 & 13 & 11 & 13 & 13 \\
\hline 4. grass $\ldots \ldots \ldots \ldots \ldots$ & 13 & 13 & 14 & 12 & 15 & 15 \\
\hline 5. asparagus, straw $\ldots \ldots \ldots$ & 15 & 16 & 15 & 13 & 15 & 15 \\
\hline 6. grass $\ldots \ldots \ldots \ldots \ldots \ldots$ & 14 & 16 & 16 & 15 & 20 & - \\
\hline 7. chicory, roots $\ldots \ldots \ldots$ & 14 & 17 & 19 & 16 & 22 & 18 \\
\hline 8. grass $\ldots \ldots \ldots \ldots \ldots \ldots$ & 19 & 20 & 20 & 18 & 24 & 18 \\
\hline 9. potato, leaves $\ldots \ldots \ldots \ldots$ & 31 & 31 & 32 & 30 & 36 & 32 \\
\hline 10. alfalfa $\ldots \ldots \ldots \ldots \ldots \ldots$ & 36 & 36 & 37 & 37 & - & 36 \\
\hline 11. apple, leaves $\ldots \ldots \ldots \ldots$ & 50 & 51 & 49 & 48 & 50 & 52 \\
\hline 12. apple, leaves $\ldots \ldots \ldots \ldots \ldots$ & 49 & 50 & 51 & 47 & 51 & 50 \\
\hline 13. leek, leaves $\ldots \ldots \ldots \ldots \ldots \ldots$ & 54 & 59 & 58 & 59 & 57 & 54 \\
\hline 14. tomato, leaves $\ldots \ldots \ldots \ldots \ldots$ & 65 & 68 & 65 & 65 & 69 & 67 \\
\hline 15. apple, leaves $\ldots \ldots \ldots \ldots \ldots$ & 63 & 66 & 72 & 60 & 68 & 68 \\
\hline 16. pear, leaves $\ldots \ldots \ldots \ldots \ldots$ & 80 & 81 & 80 & 73 & 78 & 81 \\
\hline 17. tomato, leaves $\ldots \ldots \ldots \ldots$ & 113 & 116 & 116 & 110 & 112 & 119 \\
\hline 18. tomato, leaves $\ldots \ldots \ldots \ldots$ & 127 & 134 & 131 & 127 & 132 & 136 \\
\hline 19. tomato, leaves $\ldots \ldots \ldots \ldots$ & 142 & 166 & 162 & 157 & 158 & 164 \\
\hline
\end{tabular}

Note :

Method 1: dry ashing; precipitation of calcium as oxalate; oxydimetric titration.

Meth od 2: sulphuric acid peroxide digestion; separation of phosphates; complexometric titration. Method 3: hydrochloric acid extraction; complexometric titration.

Method 4: sulphuric acid peroxide digestion; flame photometry.

Method 5: hydrochloric acid extraction; flame photometry.

Method 6: nitric-perchloric-acid digestion; precipitation of calcium as oxalate; oxydimetric titration.

hydrochloric acid extracts may lead to serious errors as is shown by samples $1,6,7$, 8 and 9. The inaccurate results are not caused by the extraction method as is shown by $\mathrm{method} \mathrm{3,} \mathrm{but} \mathrm{are} \mathrm{brought} \mathrm{about} \mathrm{by} \mathrm{an} \mathrm{incorrect} \mathrm{use} \mathrm{of} \mathrm{the} \mathrm{flame-photometer}$ as an analytical tool. However in the case of the Lindner-Harley digestion ( $\mathrm{m} \mathrm{et} \mathrm{h} \mathrm{od}$ 4) flame-photometry leads to better results. Probably dissolved organic substances which have not been adsorbed by the Norit are responsible for the anomalies.

\section{I T E R A T U R E}

Anon.

Collier, R. E.

DiEHL, H., and

J. L. Ellingboe
1955 Official methods of analysis of the Association of official agricultural Chemists. 8th Ed. Washington D.C., p. 1008.

1960 Experiment Station for Fruit and Vegetables under Glass (private communication).

1954 Extraction of phosphates prior to EDTA titration of calcium and magnesium. Chemist Analyst. 43, 41.

1956 Indicator for titration of calcium in presence of magnesium using disodium dihydrogen ethylenediaminetetraacetate. Anal. Chem. $28,882$. 
Grosse-BrauckMaNN, E. 1958 Uber den Einfluss hoher Kieselsaüregehalte im Getreidestroh auf die Bestimmungen von Calcium, Magnesium, Kalium und Natrium. Landw. Forsch. 11, 105.

LINDNER, R. C.

- and C. P. Harley

Pietka, G., and H. ChuN

SCHARRER, K., and

H. MUNK

Schouwenburg, J. Ch. van

SChuffelen, A. C.,

A. MULler and

J. CH. van SchouWendurg

TUCKER, B. M.
1944 Rapid analytical methods for some of the more common inorganic constituents of plant tissues. Pl. physiol. 19, 76.

1942 A rapid method for the determination of nitrogen in plant tissue. Science. 96, 565.

1959 Flammenphotometrie I. Angew. Chemie. 71, 276.

1956 Zur Methodik der nassen Veraschung in der agrikulturchemischen Analyse. Agrochimica. 1, 44.

1959 De bruikbaarheid van Noriet als klaringsmiddel bij grond- en gewasonderzoek. Chem. Weekblad. 55, 438.

1960 Micro-EDTA titration of calcium. Magnesium interference. Anal. Chem. 32, 709.

1961 Quick-tests for soil and plant analyses used by small laboratories. Neth. J. agric. Sci. 9, 2.

1957 Calcein as an indicator for the titration of calcium with ethylenediaminetetraacetate. The Analyst. 82, 284. 